\title{
Universiteit
}

Leiden

The Netherlands

\section{Islam in Mali in the neoliberal era}

Soares, B.F.

\section{Citation}

Soares, B. F. (2005). Islam in Mali in the neoliberal era. African

Affairs: The Journal Of The Royal African Society, 105(418), 77-95. doi:10.1093/afraf/adi088

Version: $\quad$ Not Applicable (or Unknown)

License: $\quad$ Leiden University Non-exclusive license

Downloaded from: $\quad$ https://hdl.handle.net/1887/9544

Note: To cite this publication please use the final published version (if applicable). 


\title{
ISLAM IN MALI IN THE NEOLIBERAL ERA
}

\author{
BENJAMin F. SOARES
}

\begin{abstract}
If before 11 September 2001, many praised Mali as a model of democracy, secularism and toleration, many have now begun to express concern about the rise of Islamic fundamentalism in Mali. I consider a number of recent public debates in Mali over morality, so-called women's issues, and the proposed changes in the Family Code and show how the perspectives of many Malians on these issues are not new but rather relate to longstanding and ongoing debates about Islam, secularism, politics, morality and law. What is new is the way in which some Muslim religious leaders have been articulating their complaints and criticisms. Since the guarantee of the freedom of expression and association in the early 1990s, there has been a proliferation of independent newspapers and private radio stations and new Islamic associations with a coterie of increasingly media-savvy activists. I explore how some Muslim activists have used such outlets to articulate the concerns of some ordinary Malians, who face the contradictions of living as modern Muslim citizens in a modernizing and secularizing state where, in this age of neoliberal governmentality, the allegedly unIslamic seems to be always just around the corner.
\end{abstract}

AT THE END OF THE TWENTIETH CENTURY, Mali - one of the world's poorest countries - had become one of the top ten recipients of foreign aid in the world. In the post-Cold War era, the United States, European donor countries and multilateral lending agencies have all regularly praised Mali as a model for the transition to democracy, the implementation of economic reforms and liberalization. For more than a decade, Mali has tended to meet International Monetary Fund and World Bank targets and timetables for structural adjustment programmes, privatization schemes and reductions in state budget deficits. One recent US Agency for International Development (USAID) publication has even called Mali — without any

Benjamin F. Soares (bsoares@fsw.leidenuniv.nl) is at the Afrika Studiecentrum, Leiden. Portions of the paper have been presented at the workshop, 'Islam, Society and State in West Africa', Rutgers University, New Brunswick, 29 March 2003; at the symposium, 'Construction and Dissemination of Islamic Knowledge in Africa', Indiana University, Bloomington, 19 April 2003; and at the conference, 'Governance and Insecurity in West Africa', Northwestern University, 13-15 November 2003; and at Universität Bayreuth. I am grateful to the Melville J. Herskovits Library of Africana Studies at Northwestern University for its incomparable collection of Malian newspapers. I would also like to thank Moussa Djiré, Barbara Lewis, Marie Miran, and especially Mark LeVine and Armando Salvatore for invaluable comments and suggestions. 
apparent irony - a 'poster child' for such reforms. ${ }^{1}$ It would seem that Mali's compliance, which lenders and donors often link to 'good governance', has helped to keep massive aid and loans flowing into the country.

The geopolitical and strategic interests and objectives of some of Mali's major donors are usually hidden from view beneath streams of data and oft-repeated arguments about the necessities and benefits of Washington Consensus reforms of Mali's economy. Yet, it remains clear that at least since the early 1990s both US and EU policy makers have seen Mali with its long borders with Mauritania and Algeria, in the words of the Economist Intelligence Unit, 'as a bulwark against radical Islam in Africa' ${ }^{2}$ Mali received praise on the international stage as a model of toleration and for its commitment to laïcité or secularism and after 11 September 2001 was held up as 'the sole exemplar of freedom in a majority-Muslim country' in the world ${ }^{3}$ but this changed shortly thereafter. Official US government publications have begun to warn that Mali is 'a potential breeding ground for Islamic fundamentalists', 4 and official US policy of 'outreach' to Muslims has been intensified in Mali and elsewhere. In the time leading up to the 2002 presidential elections in Mali, certain commentators - policy makers and journalists in particular — seemed genuinely surprised that Muslim religious leaders in Mali were 'suddenly' complaining vocally about 'how Mali's secular state was [being] run'.5 Some of Mali's Muslim religious leaders had specific political demands and even openly supported political candidates and parties, which many have interpreted as evidence of rising 'political Islam' and even a rampant and dangerous 'Islamism' in the country. ${ }^{6}$ But the so-called complaints of Muslim religious leaders in Mali were neither sudden nor new. As I will suggest, they relate to longstanding and ongoing debates about Islam, laïcité or secularism, and politics in Mali. What was new by 2002 was the way in which certain Muslim religious leaders and activists articulated their complaints and criticisms. In this age of neoliberalism and governance 'from afar', ${ }^{7}$ new forms of associational

1. United States Agency for International Development, 'Assistance environment', in USAID MALI: Country Strategic Plan 2003-2012 (USAID, Bamako, Mali, 2002), p. 11.

2. Economist Intelligence Unit, 'The political scene', in EIU Country Report: Mali (EIU, London, March 2002), p. 47.

3. See Joshua Muravchik, 'Freedom and the Arab world', The Weekly Standard, 31 December 2001.

4. 'Overview'. USAID MALI: Country Strategic Plan 2003-2012 (USAID, Bamako, Mali, 2002), p. 18. Such sentiments were also expressed in journalistic accounts published shortly after 11 September 2001. See, for example, Douglas Farah, 'Mali's Muslim clerics send troubling message: fragile democracy seen as vulnerable to extremism', Washington Post, 30 September 2001, p. A24; Kader Konaté, 'Mali. Le danger islamiste', Le Continent, 14 September 2001, p. 1. 5. See Joan Baxter, 'Challenging tradition', BBC Focus on Africa Magazine, January-March 2002, pp. 48-50. Other examples include Nicolas Colombant, 'Mali's Muslims steer back to spiritual roots', Christian Science Monitor, 26 February 2002, p. 8.

6. These included various Western media outlets and several Malian newspapers.

7. James Ferguson and Akhil Gupta, 'Spatializing states: toward an ethnography of neoliberal governmentality', American Ethnologist 29, 4 (2002), pp. 981-1002. 
life, increased transnational and global interconnections and the use of new media technologies have helped to change the terms and conditions of debate. A consideration of some of the recent debates about Islam, secularism and politics in Mali forces us to rethink some of the assumptions many have made about the prospects for 'civil society' - one of the much vaunted panaceas for the world's problems - in Muslim-majority countries in particular and in postcolonial societies more generally. ${ }^{8}$

\section{fuxtapositions}

I want to begin by emphasizing the importance of understanding Mali as a place of many contradictions and often jarring juxtapositions and syntheses. Although such a statement might seem utterly banal, possibly even an anthropological fantasy, such juxtapositions include Islam, on the one hand, and what we might call 'fetishism', 'animism', 'paganism' or African 'traditional' religion on the other; Muslim and non-Muslim; African and Western. If it has become almost de rigueur for social scientists to identify various kinds of cultural hybridities in the societies we study, such an analytical frame is inadequate to the task of helping us to make sense of contemporary Mali and its history.

Mali is a place where Islam has been practiced for at least a millennium. Islam is incredibly important here, which is not to say that all Malians are Muslims. Although Mali is overwhelmingly Muslim, there is no uniform way of being Muslim. However, Islam has a central place in the social and historical imagination in Mali. Malians regularly make reference to such renowned centres of Islamic learning in the country as Timbuktu and Djenné - to cite only those known outside of Mali. Malians also regularly invoke Muslim rulers of various pre-colonial states and empires and past Muslim clerics, saints, and miracle workers from the distant and more recent colonial and postcolonial past. ${ }^{9}$ Such past historical and mythical figures have complex relations to both anti-colonial and nationalist discourses, as well as regional inflections, to which I can only allude. At the same time, Mali is a place where what purportedly lies outside of Islam that is, the un-Islamic or the non-Islamic (which is not to say 'Western') figures very prominently. In fact, there is also a range of historical and

8. For critical perspectives on the fashionable civil society approach to 'good governance' in Africa, see John L. Comaroff and Jean Comaroff (eds), Civil Society and the Political Imagination in Africa (University of Chicago Press, Chicago, IL, 1999); Béatrice Hibou and Richard Banégas, 'Civil society and the public space in Africa', CODESRIA Bulletin 1 (2000), pp. 39-47.

9. For example, Sunjata, the mythical founder of the medieval Malian empire, Mansa Musa, the Muslim rulers of Macina (r. nineteenth century), al-Hajj Umar Tall (d. nineteenth century), the Kunta shaykhs of the Timbuktu region, and Shaykh Hamallah (d. twentieth century), to name only some of the most prominent. 
mythical non-Muslim figures Malians regularly invoke, sometimes alongside Muslim figures. Similarly, allegedly un-Islamic centres, capitals and spaces dot the landscape and are also part of the imaginary. It is of course a crucial question as to who gets to decide what is or is not Islam or Islamic 'orthodoxy' if you will - and how such orthodoxy might change over time. ${ }^{10}$

One does not have to travel away from the main metropolitan areas in Mali to get a sense of such juxtapositions. Although anthropologists have recently drawn on fieldwork in far-flung places and among seemingly marginal groups to emphasize their 'modernity' and long involvement in globalized worlds, ${ }^{11}$ I prefer to focus on Bamako, the colonial city that became the capital of postcolonial Mali. The most populous city in Mali, Bamako is also the country's most important centre of economic activity, politics, education, cultural activity and international assistance, since Mali, on the French model, remains a highly centralized state. Readily available for sale at the back of the large imposing modern main Friday mosque located in the heart of central Bamako in a congested part of the city are ingredients for what was called 'fetishism' in the colonial lexicon, and, now usually, 'traditional' African religion or 'medicine'. Such objects as dried and cured animal parts (horns, skulls, hands and quills of bush animals) are being bought and sold alongside copper vessels used in writing 'magical' and therapeutic texts and a wide array of plant medicines, some of which are now being marketed like Western pharmaceuticals. While it is usually very difficult for many scholars working in Muslim West Africa not to hone in on the exotic, my description of what might seem the contents of a curiosity cabinet has a purpose other than the narrowly exoticizing. All of these 'traditional' objects are for sale in a space more or less separate from where other vendors sell more unambiguously Muslim objects, indeed, 'modern' Islamic religious commodities - copies of the Quran, prayer beads, print media about Islam and copies of the country's most popular Muslim preachers' sermons on cassette. ${ }^{12}$

Just a few steps away from these markets are the offices of Radio Islamique, the Islamic radio station, housed in a building in the mosque complex. Since 1994, Radio Islamique has aired regular radio programming in which Muslim preachers, mostly reformist Muslims, though in some cases prominent members of the country's main Sufi orders, exhort Malians

10. For an example of how such 'orthodoxy' changes over time and space in Mali, see Benjamin F. Soares, 'Muslim proselytization as purification: religious pluralism and conflict in contemporary Mali' in Abdallah A. An-Na'im (ed.), Proselytization and Communal SelfDetermination in Africa (Orbis, Maryknoll, NY, 1999), pp. 228-45.

11. Two studies that have received quite a bit of attention are Anna L. Tsing, In the Realm of the Diamond Queen: Marginality in an out-of-the-way place (Princeton University Press, Princeton, NJ, 1993); Charles Piot, Remotely Global: Village modernity in West Africa (University of Chicago Press, Chicago, IL, 1999).

12. See Gregory Starrett, 'The political economy of religious commodities in Cairo', American Anthropologist 97, 1 (1995), pp. 51-68. 
in often moralistic language about how to conduct themselves as proper modern Muslims. The presumably correct way of being Muslim involves a standardized set of ritual norms - regular ritual daily prayer, fasting during the month of Ramadan and alms giving - that have become much more widespread among Malian Muslims regardless of social distinctions (hereditary or otherwise) over the past few decades. ${ }^{13}$ The way of being Muslim espoused on the radio also involves the shaping of moral subjects in contemporary Malian society. Most notably, this is said to entail giving up and avoiding 'fetishism', including the kind for which ingredients are sold just steps away, as well as eschewing a wide array of other allegedly un-Islamic objects and practices, some judged more reprehensible than others.

A recurrent motif in the discourse of many Malian Muslim preachers (and laypersons) is that a number of reprehensible things have been more readily available to Malians since the 1991 coup that replaced the authoritarian regime of President Moussa Traoré with a transitional government eventually leading to multi-party elections in 1992. Not far from Radio Islamique, there are kiosks - as there are throughout the city - where one can place bets on French horse races through the French gambling corporation, le Pari mutuel urbain du Mali or the PMU. This is the gambling for the masses that arrived shortly after the multi-party elections and the accelerated implementation of neoliberal reforms. On Thursday evenings, one can find out the betting results on Malian national television less than an hour before the programme, Magazine Islamique, airs. This weekly programme, which sometimes features preachers whose sermons are played on Radio Islamique, is broadcast in anticipation of the weekly communal prayers that many Malian Muslims perform on Fridays. Earlier in the evening, one might catch a South American telenovela dubbed in French, a programme highlighting Mali's cultural heritage, or maybe even an African beauty pageant. ${ }^{14}$ The many Malians without access to television can catch the betting results on Malian national radio before the longrunning radio programme, Les Règles de l'Islam (The Rules of Islam), which features some of the same preachers involved in Radio Islamique. It is my contention that one cannot begin to understand contemporary Mali without making sense of some of these juxtapositions about which there has been much debate and discussion in Mali.

13. On these developments, see Robert Launay and Benjamin F. Soares, 'The formation of an "Islamic sphere" in French colonial West Africa', Economy and Society, 28, 4 (1999), pp. 497-519; Benjamin F. Soares, 'Islam and public piety in Mali', in Armando Salvatore and Dale F. Eickelman (eds), Public Islam and the Common Good (Brill, Leiden, The Netherlands, 2004); Benjamin F. Soares, Islam and the Prayer Economy: History and authority in a Malian town (Edinburgh University Press, Edinburgh and the University of Michigan Press, Ann Arbor, 2005).

14. Malians with access to satellite television have a wider array of choices, which are hard to quantify. 


\section{In the postcolony}

Just steps away from the two markets for diverse 'modern' and 'traditional' religious commodities, the offices of Radio Islamique and the main Friday mosque, is the building of the Malian National Assembly where elected deputies meet. As I have noted, the first multi-party elections were held in 1992, and, ten years later, Mali had the distinction of becoming one of the first African countries to have two successive democratically elected presidents. One of the many things the postcolonial Malian state inherited from France and the colonial state is the idea that the state is to be laïc or secular. ${ }^{15}$ Following the French model, religion is understood as private and confessional. In such a conception of religion as privatized belief, the state is expected not to intervene in religious matters. But secularism is arguably a derivative discourse in postcolonial Mali in ways similar to how nationalism is a derivative discourse in India and other postcolonial societies. ${ }^{16}$ Since independence in 1960, every Malian government from the first postcolonial socialist regime to the most recent democratically elected one has sought to associate itself with Islam and with certain public expressions of Islam. While the ostensibly secular colonial state also actively sought to associate itself with Islam, the difference is that every postcolonial Malian ruler has been Muslim and has endeavoured to present himself publicly as such. Much like its colonial predecessor, the secular postcolonial Malian state has also made some rather conspicuous interventions in realms deemed religious.

Secularism in practice in Mali has quite often been fraught with contradictions as the following examples suggest. Radio Islamique in Bamako was actually founded in 1994 by prominent members of AMUPI, L'Association malienne pour l'unité et le progrès de l'islam (the Malian Association for the Unity and Progress of Islam), which the Malian government launched in 1980 as the country's sole officially authorized Islamic association. Founded as it was in the wake of the Iranian revolution, AMUPI was explicitly designed to manage conflict and tensions between reformist Muslims and those affiliated with Sufi orders with whom they often disagree about Islamic religious practice and leadership of the Muslim community. AMUPI was also officially responsible for coordinating the considerable financial assistance from Muslim countries such as Saudi Arabia, Libya, Iran and the Gulf states for mosques, education and Islamic cultural centres. Given the state's new commitment to freedom of association after 1991, Malians founded many new Islamic associations, and AMUPI was no longer the country's only officially recognized Islamic association. In the last few years, the Malian

15. Some of the themes in this section are treated at greater length in my book, Islam and the Prayer Economy.

16. Partha Chatterjee, The Nation and Its Fragments (Princeton University Press, Princeton, NJ, 1993). 
government has promoted - again on the French model - a 'High Islamic Council' (Haut conseil Islamique). Much like the recent French government-initiated Conseil français du culte musulman (CFCM), the Haut conseil Islamique will presumably represent all Muslims and act as the 'official and unique interlocutor of political authorities for all questions relative to the practice of Islam' ${ }^{17}$ Such initiatives clearly relate to the state's ongoing efforts to regulate and monitor the activities of Muslim religious specialists and Muslims more generally. At the same time, they must be understood in relation to the history of colonialism (from the late 19th century until 1960) and the postcolonial period. One of the truly striking continuities from the colonial period until the present age of neoliberalism is how Islam and Muslims are almost invariably assumed to be among the most significant potential problems for governance.

During the colonial period, the French colonial administration generally sought to restrict Muslim religious specialists' activities to the narrowly religious and educational spheres, such as prayer, lifecycle rituals, Quranic education and the running of Sufi orders. 'There were always important exceptions, such as ... [those members] of the "loyal" Muslim establishment, whose interventions in politics, religion and public policy were integral to the colonial administration's policies towards Islam and Muslims' ${ }^{18}$ Similarly, certain Muslim religious leaders - various leaders of Sufi orders and living Muslim saints, often referred to as marabouts - have had close ties with high-ranking officials of the postcolonial state, including those in recent democratically elected governments.

Although the Malian state uses European-derived codes of law, Muslims in Mali regularly apply Islamic legal principles derived from fiqh (Arabic jurisprudence) and the Maliki school of jurisprudence in particular in the conduct of their personal lives and affairs. ${ }^{19}$ For example, Muslim merchants often rely upon and make reference to such principles in the conduct of commerce, including the prohibition on interest as well as on auctions. Many Muslims in Mali also ordinarily apply Islamic legal principles in areas of so-called family law, including marriage, divorce and inheritance. ${ }^{20}$ This is the case even though such principles sometimes conflict with postcolonial Malian law. Many ordinary Muslim religious specialists in the country

17. See Seydina Oumar Diarra, 'Haut Conseil Islamique du Mali', Info-Matin, 18 January 2002 , p. 5.

18. Benjamin F. Soares, Islam and the Prayer Economy, p. 212. See also David Robinson, Paths of Accommodation: Muslim societies and French colonial authorities in Senegal and Mauritania, 1880-1920 (Ohio University Press, Athens, OA, 2000); David Robinson and Jean-Louis Triaud (eds), Le temps des marabouts: Itinéraires et stratégies islamiques en Afrique occidentale française v.1880-1960 (Karthala, Paris, 1997).

19. Many Malians also regularly apply diverse principles from 'custom', which is often referred to as laada (from the Arabic) in the region's vernaculars.

20. For one example, see Benjamin F. Soares, 'Notes on the anthropological study of Islam and Muslim societies in Africa', Culture and Religion, 1, 2 (2000), pp. 277-85. 
regularly advise people on how to conform to Islamic legal principles. For example, one recently deceased Malian Muslim scholar, Ahmad Uthman Bah, who was known for some of his written work, ${ }^{21}$ had an even more widespread reputation for his expertise in matters of inheritance. Many people throughout the country sought him out for his authoritative Islamic jurisprudential knowledge either to resolve disputes over inheritance or prevent them from arising. In sermons and in published works, many other Muslims give more general instruction on how to conduct oneself as a Muslim. ${ }^{22}$ The sermons on audio and videocassette (and more recently on digital video disk) of Muslim preachers, including those of the country's most important Muslim media star, Chérif Ousmane Madani Haïdara, can be included here. ${ }^{23}$ In the secular postcolonial state, any such instruction or advice is of course not compulsory. However, the progressive marginalization of Islamic jurisprudence and Muslim religious specialists during the colonial period and after in Mali has paradoxically not led to the kinds of intense debates about shari'a witnessed recently in other countries such as Nigeria. While most Muslim religious leaders in Mali regularly invoke shari' $a$, there are relatively few Malians arguing that shari'a be made into state law.

If education and French language secular schooling were particularly central to the colonial project in West Africa, such education has been no less important in postcolonial Mali. The bureaucrats, civil servants, technical and administrative experts and personnel involved in the running of the affairs of the so-called modern sectors of the economy and state have been educated for the most part in the French language schools the state has promoted. This has helped to marginalize most Muslim religious specialists, including modernist and reformist Muslims, along with proponents of Sufi orders, with their expert religious knowledge premised on literacy in Arabic. Moreover, many of those who have come to complete French language secular schooling see Muslim religious specialists and their knowledge, including the Islamic jurisprudence many continue to study and teach, as outmoded, if not explicitly reactionary.

Over the past several decades, many Malian Muslims, including religious specialists, have been active in areas beyond their restricted 'traditional' religious and educational activities. Many have been involved as founders, financial backers and teachers in the new private Islamic educational institutions called madrasas in Mali where fee-paying students receive a modern

21. Ahmad Uthman Bah, Diya' al-ghasaq manzuma nasihat al-shabab (Matba'at al-najah al-jadida, Casablanca, Morocco, 1992).

22. See, for example, Amadou Tall, Dimensions de l'Islam (Dar El Fikr, Beirut, Lebanon, 1995-1996).

23. On Haïdara and his career, see Soares, 'Islam and public piety' and Soares, Islam and the Prayer Economy. Cf. Dorothea Schulz, "CCharisma and Brotherhood" revisited', fournal of Religion in Africa, 33 (2003), pp. 146-71. 
education in Arabic along with an Islamic religious education. ${ }^{24}$ Although some madrasas provide limited instruction in French, many do not. The spread of these private schools relates to the educational and financial ties with the Arab Middle East that have intensified since the 1970s. A considerable number of madrasa graduates have gone on for advanced Islamic religious education abroad, particularly to Egypt and Saudi Arabia. Upon return, many graduates with their expert religious knowledge and education in Arabic have had difficulties entering those sectors of the economy where literacy in French is a prerequisite.

After the 1991 coup, the new Malian constitution reaffirmed the principle of secularism and religiously based political parties were not permitted. Given the state's greater commitment to freedom of association and expression, there has been a proliferation of new associations and organizations, as well as newspapers and radio stations in the country. Mali, like many other places, is now teeming with all sorts of new non-governmental organizations (NGOs) and associations - some of the alleged building blocks of civil society. Organizations which have diverse transnational connections for funding, personnel and support focus on health, education, women's issues, human rights and development. Some of these NGOs thus operate in areas where the state's involvement has been cut back in accordance with neoliberal prescriptions.

Some of these new associations and NGOs are specifically Islamic in orientation, and, for this reason, Western donors largely ignored them prior to 11 September 2001. There are many dozens of new Islamic associations in Mali, most of which are not only urban based, but usually restricted to Bamako and other urban centres in the country. They include Muslim youth, women's, and reformist Muslim associations, as well as Islamic associations promoting development. If some are Islamic NGOs with complex transnational connections, many more are trying to raise funds for the construction of mosques, schools and development projects from local wealthy donors or overseas, often without much success. Most of the founders, leaders and activists in these Islamic associations are madrasa graduates or those with a more 'traditional' Islamic education. Many are Muslim intellectuals, who are members of a new highly educated postcolonial Muslim elite with complex transnational ties and sometimes affiliations. ${ }^{25}$ Many members of this elite actively foster a standardized set of ritual norms, including regular ritual daily prayer, and they often focus explicitly on the shaping of moral subjects in the broader public sphere. Indeed,

24. See Louis Brenner, Controlling Knowledge: Religion, power and schooling in a West African Muslim society (Indiana University Press, Bloomington, IL, 2001).

25. Cf. Olivier Roy (trans. C. Volk), The Failure of Political Islam (Harvard University Press, Cambridge, 1994); Olivier Roy, Globalized Islam (Columbia University Press, New York, NY, 2004). 
many of them are concerned with a very public, deprivatized Islam, ${ }^{26}$ whereby modern Muslim subjects eschew the allegedly un-Islamic whether it might be 'African' or from 'the West'. Although this new Muslim elite includes members of Sufi orders and their reformist Muslim critics, it is striking how few members of this elite have large constituencies. The one exception is the Muslim media star Chérif Haïdara, who despite being a modern preacher and the head of a large modern Islamic association, Ançar Dine, nonetheless tends to comport himself much like a conventional leader of a Sufi order, living Muslim saint or marabout. ${ }^{27}$ Aside from this one religious leader, no other member of the new Muslim elite has been able to supplant the country's Sufi leaders, Muslim saints and marabouts, who live in certain Islamic religious centres outside the capital. In spite of sustained efforts and bids to represent ordinary Muslims or speak on their behalf since the 1990s, most members of the new Bamako-based Muslim elite lack religious authority and consequently do not have many followers.

\section{Public debates}

In the early 1990s after the coup, the mood in Mali was quite optimistic. Rapid economic growth, investment in infrastructure, a construction boom, the flourishing of new political parties, associations and the development of a very lively press and private radio stations fuelled the optimism. With ongoing student strikes, disruption of state schools, the Tuareg/Arab uprising in parts of the country, intense political infighting, segmentation and electoral chaos, the mood became much more sombre. The early 1994 devaluation of the CFA-franc currency by 50 percent - in accordance with neoliberal prescriptions - and the subsequent economic decline many Malians experienced only made matters worse. But even before the general optimism had dissipated, some Malians had a number of specific concerns, complaints and dissatisfactions, which they sometimes articulated in relation to Islam, Muslim values, morality and so forth. In fact, various Muslim activists and Islamic associations have played a central role in articulating some of these concerns in a series of important and sometimes acrimonious debates, the most important of which I shall briefly discuss.

Shortly after the 1991 coup, certain prominent Muslim religious leaders in Mali made public statements where they expressed concern that everything now seemed to be permitted in the society. ${ }^{28}$ During fieldwork in the

26. Cf. Armando Salvatore, 'Social differentiation, moral authority and public Islam in Egypt: the case of Mustafa Mahmud', Anthropology Today, 6, 2 (2000), pp. 12-15.

27. For a discussion of Haïdara and his association's relation to Sufism and Sufi orders, see Soares, Islam and the Prayer Economy.

28. This was also a topic of discussion in some print media. See, for example, Cheick Sidya Diombana, 'La jeunesse et la foi en l'Islam', La Roue, 25 October-3 November 1993, p. 5. 
1990s, I frequently heard ordinary Malians discuss and lament the general climate of permissiveness, lax morals and moral corruption, which seemed to accompany the much-welcomed removal of the authoritarian regime of Moussa Traoré. In a direct reversal of the Traoré regime's policy to close bars and nightclubs during the month of Ramadan, such establishments were permitted to remain open. Many Malians were very unhappy about this, and there was considerable discussion of the change in policy. Malian secularists argued that closing bars and nightclubs during Ramadan had been a violation of the principle of secularism; allowing them to remain open was to uphold this inviolable principle. But I heard some Malian Muslims say such an argument was disingenuous since bars and nightclubs had more to do with the tourist industry the Malian state was attempting to promote through economic liberalization policies. After all, one cannot hope to attract tourists, especially Western tourists, without bars and nightclubs. With economic liberalization, all sorts of entrepreneurs were relatively free to open places of business, and bars, large and small, popped up throughout the capital.

Many Malians were alarmed and angry that the new openness in the society meant that pornographic films were being screened in cinemas open to all. In the early 1990s, some Malians actually made threats of violence against those cinemas showing such films. In 1992, a handwritten sign in French pasted on a cinema in central Bamako warned:

In the name of God, the Compassionate, the Merciful. NOTICE. We ask the management . . . to stop the advertising [and] the screening of pornographic films. If not, we are going to ransack the cinema. Inshallah. Thank you. ${ }^{29}$

Although most of the cinemas in Bamako and elsewhere in the country ceased to operate shortly thereafter, this seems to have been due to the proliferation of the video cassette recorder rather than any such threats. As the video cassette recorder was starting to become more widely available, pornographic films could be watched in the privacy of one's home. Indeed, with the spread of the video cassette recorder, the debate about the public screening of pornographic films ended though related debates about new alleged threats to morality continued apace. Indeed, a main target of criticism was one area in which there has been massive investment and growth in the era of economic liberalization: the maison de passe (as it is called in Mali) where people, usually unmarried couples, can rent rooms by the hour. Hotel and bar owners and other investors had opened such establishments throughout the city, and some, including several catering to the wealthy, were now operating quite openly near mosques and madrasas. Some of these entrepreneurs were apparently turning a handsome profit and making additional investments in this and the related hotel sector.

29. I am grateful to Roman Loimeier for making his copy of this sign available to me. 
Another highly contentious issue has been gambling. Although Muslim religious leaders in Mali have universally denounced the gambling for the masses of the PMU and condemned it as forbidden according to the precepts of Islam, this does not mean that ordinary Malian Muslims do not gamble. To the contrary, I know many men who while fasting during the month of Ramadan spend a good part of the day deciding on which horses to bet. However, many Malian Muslims saw the opening of the country's first casino - a gambling venue for the well heeled - in central Bamako as a further outrage. If ordinary Malians place their bets on horses at the ubiquitous PMU kiosks in urban public spaces, casino-goers get to place their own bets outside the view of inquiring eyes in the concealed private space of the casino with its alleged European underworld connections.

If Muslim debate and dissatisfaction had initially been somewhat dispersed, focused on the general laxness of morals or climate of permissiveness and sometimes specifically on pornography or gambling, this changed in the mid-1990s when Islamic associations took centre stage in debates about various women's issues. After the United Nations' Fourth World Conference on Women in Beijing in 1995 in which Malians had enthusiastically participated, Malian Islamic associations organized large public meetings where Muslim men and women gathered. Invoking 'Islamic values', they issued public statements in which they objected to the Beijing women's conference 'Declaration and Platform for Action for Women's Rights as Muslims' in ways that were not entirely unpredictable. ${ }^{30}$ Indeed, some of their objections chimed with those advanced by Muslim-majority countries such as Iran. The Malian Islamic associations specifically criticized the Malian women's secular NGOs that had participated in the UN conference and had supported the Platform for Action for trying to advance what they considered a Western secular agenda and Western values more generally.

Another issue that has also generated much debate in Mali is excision or female circumcision. Since the 1994 UN Population and Development conference in Cairo when individual countries were urged to eliminate excision, UN agencies, the Catholic Church, various bilateral donors and Malian NGOs have been involved in campaigns against excision in Mali. ${ }^{31}$

30. See, for example, 'Déclaration finale des associations islamiques du Mali concernant les valeurs islamiques et à propos du programme d'action de Beijing rélatif aux droits des femmes', La Roue, 22-31 January 1996, pp. 3-5.

31. For a discussion of some of the controversy around excision, see Bettina Shell-Duncan and Ylva Hernlund (eds), Female 'Circumcision' in Africa: Culture, controversy, and change (Lynne Rienner, Boulder, Colorado, 2000). For campaigns against excision in Mali, see Claudie Gosselin, 'Handing over the knife: Numu women and the campaign against excision in Mali', in Bettina Shell-Duncan and Ylva Hernlund (eds), Female 'Circumcision' in Africa, pp. 193-214; Jean Sanou, 'Lutte contre les mutilations génitales feminines', Le Soudanais, 22 November 2000, p. 3; Yousouf Camara, 'Réligion et excision', Le Tambour, 22 June 2001, p. 3; Mamadou Blodin Sissok, 'Religion et excision. Quand les chrétiens s'engagent contre les mutilations génitales féminines', Info-Matin, 29 June 2001, p. 8. 
One of the most prominent Malian women's rights activists, Fatoumata Siré Diakité, a former school teacher, union activist, head of the Malian NGO, Association pour la promotion et la défense des droits de la femme, and recipient of France's Légion d'honneur, has been in the forefront of the antiexcision campaigns in Mali. In fact, Diakité has been the most vocal person in Mali calling for an outright ban on excision. Along with other Malian women's rights activists and prominent Malian secularists, she has also tried to advance the argument that excision - unlike male circumcision - is not part of Islam. ${ }^{32}$ However, many Malian Muslims think the exact opposite is true. In the debates about excision, Muslim religious leaders and activists from different Islamic associations have claimed that excision, just like male circumcision, is actually an Islamic religious practice, which can and should eventually be 'medicalized'. ${ }^{33}$ Some Malian Muslims have reacted angrily to the organized campaigns against excision in the country, which have relied upon Malian NGOs like Diakité's and have used theatre, music and the mass media to spread their messages against excision. Many have denounced those involved in anti-excision campaigns as advocating the imposition of Western values on Malian Muslims. On several occasions, Islamic associations in Mali have publicly accused Western-funded NGOs of meddling in Mali's internal affairs. One leader of an Islamic association in Mali has even decried what he calls 'the crusade' of 'immoral Westerners' working with hypocritical Malians 'who...are [basically] swindling NGOs out of their money [d'escroquer l'argent des $O N G$ ] in anti-excision campaigns. ${ }^{34}$ Another Islamic association that has been very active in countering the anti-excision campaigns has had its members hand out leaflets at mosques, which say (in French): 'Any law against excision, [which is] a practice of the Sunna [that is, the authoritative practice of the Prophet Muhammad] is an attack on the freedom of religion' and 'blasphemy'. 35

By the late 1990s, there was much talk of how Muslim values were not being respected and the dangers of the onslaught of Western values. For example, prominent members of the government-initiated AMUPI protested against what they called 'the general manner in which Islam suffered from attack' in the country. ${ }^{36}$ However, AMUPI was not alone in voicing

32. See, for example, Mady M. Dembélé, 'L'excision est un poids des traditions, elle n'a rien de religieux', Les Echos, 18 July 2001, p. 5.

33. See C.H. Sylla, 'Interview exclusive. Le Président du Collectif des islamistes parle', Le Républicain, 16 May 2001, pp. 1, 4-5; Mohamed Kimbiri, 'L'excision au Mali. La position des musulmans', Nouvel Horizon, 30 January 2001, p. 5; Mohamed Kimbiri, 'Interdire l'excision est une atteinte grave', Le Républicain, 31 January 2001, p. 5.

34. 'Brèves', Le Politicien Musulman, 18 March-18 April 2002, p. 8.

35. Leaflets produced and distributed by AISLAM (Association islamique du salut) in the author's possession.

36. See Mamadou Keïta, 'Les imams à l'affût des jouisseurs', Nouvel Horizon, 23 November 1998 , p. 4. 
such concerns. Various individual Muslim activists and spokespersons from Islamic associations openly blamed the Malian government for what they saw as a deplorable state of affairs. On a number of occasions in the late 1990s, certain Muslim activists openly protested to the government. In 1998, prominent Muslim intellectuals and Islamic associations called for a boycott of the beauty pageant for Miss CEDEAO, the Communauté Economique des Etats de l'Afrique de l'Ouest or ECOWAS, the Economic Community of West African States. With Mali hosting the beauty pageant, Malian president Alpha Oumar Konaré and his wife, Adam Ba, a wellknown historian, were to have official roles in the event. Some Muslim activists denounced the pageant with some presenting the Islamic feminist case against beauty pageants for the objectification of women. ${ }^{37}$ Interestingly, the preacher Chérif Haïdara accused those calling for the boycott of being hypocrites since they had never condemned beauty pageants staged in Mali in the past. Towards the end of 1999, there was also protest from Islamic associations and even alleged threats of violence after unconfirmed reports that a previously unheard of organization was to hold a meeting of homosexuals Le Congrès des homosexuels - in Bamako in 2000. ${ }^{38}$ Many saw Western values such as the social acceptance of homosexuality as repugnant, as they did the active promotion of the use of the condom against HIV/AIDS and family planning, more generally, by the Malian government, including President Konaré, Western donors, international organizations and local NGOs. ${ }^{39}$

As Talal Asad has argued, from 'the point of view of secularism, religion has the option either of confining itself to private belief and worship or of engaging in public talk that makes no demand on life. ${ }^{40}$ This is, indeed, one of the conundrums some Malian Muslims face. A related conundrum is that they often risk being denounced as 'fundamentalists' or 'Islamists' when they do speak publicly. Some Malian Muslims are quite aware of this. It is useful to quote Mahmoud Dicko, the imam of a reformist mosque in Bamako, who has served as an official in AMUPI, director of Radio islamique, and most recently was elected to the Haut conseil islamique. In 2000, Dicko stated in an interview:

Fundamentalism is not only religious. Fundamentalism exists in all domains. Even what we are living today is from fundamentalism; it is in part intolerance. No leader has the freedom to govern his country as he wants. They impose ways of doing things

37. Mohamed Kimbiri, 'Boycottons "Miss Cedeao" ', Nouvel Horizon, 16 October 1998. See also Mamadou Keïta, 'Miss Cedeao', Nouvel Horizon, 2 November 1998, p. 5.

38. Yoro Sow, 'Incertitudes pour la tenue du Congrès des homosexuels', Sud Info, 8 December 1999, p. 4.

39. However, some prominent Muslim religious leaders, most notably Chérif Haïdara, would eventually take positions in support of condom use. See Benjamin Soares, 'Mali: Im Visier der Islamismus-Fahnder', INAMO 41 (2005), pp. 16-18.

40. Talal Asad, 'Religion, nation-state, secularism', in Peter van der Veer and Hartmut Lehmann (eds), Nation and Religion: Perspectives on Europe and Asia (Princeton University Press, Princeton, NJ, 1999), p. 191. 
on us. Good governance is not from us, they impose it on us, and, if we refuse, they cut off credits, they cut off aid, they cut off everything, they punish you through the media, they make you into a monster. Therefore, this is all in reality a certain kind of fundamentalism, intolerance. ${ }^{41}$

On behalf of an umbrella organization of Islamic associations, the Collectif des associations islamiques $d u$ Mali, which eventually entered national politics by endorsing a presidential candidate, the seemingly omnipresent Mahmoud Dicko offered a searing critique of Malian society and its politicians. Dicko wrote that the Collectif condemned 'politicians who during the last decade have made no effort to fight against or even simply to condemn the degrading, pleasure-seeking permissiveness [permissivités ludiques dégradantes], which gains ground in our country and also and even more the socio-cultural mimicry [mimétisme socioculturel] that drains the reference points for our identity. ${ }^{42}$ It is worth noting that the 'socio-cultural mimicry' Dicko deplores is perhaps not entirely different from the playful and potentially subversive 'mimicry' and 'hybridities' Michael Taussig, Homi Bhabha and their imitators like to celebrate. ${ }^{43}$

In 2001, many Muslims in Mali were preparing for the meeting of the Organization of Islamic Conference (OIC) to be held in Bamako, where there was the usual heightened sense of the umma, the global Islamic community, focusing the attention of Muslims on Muslim issues, particularly the plight of Muslims in various places in the world, most notably, in Palestine and Iraq. ${ }^{44}$ With preparations for the OIC meeting underway, the Malian government hosted a meeting of traditional West African hunters whose practices are closely identified with the un-Islamic. ${ }^{45}$ Many Malian Muslims found it deeply offensive that the state seemed to be celebrating and thereby endorsing the hunters' un-Islamic traditions. Not only did the minister of Culture address the conferees in full hunter's garb while sporting the requisite 'fetishes' but also the Malian government proceeded to build a monument to the ostensibly non-Muslim hunters in the capital — just one part of a larger project to build national monuments in the country.

41. Djibril Traoré, 'El Hadji Mahmoud Dicko,' Le National, 2 October 2000, p. 5.

42. El Hadj Mahmoud Dicko, 'Declaration du Collectif des associations islamiques du Mali', Info-Matin, 7 May 2001, p. 7. See also El Hadj Mahmoud Dicko, 'Déclaration', Le Républicain, 4 May 2001, p. 7; Amara Diapy Diawara, 'Meeting du Collectif des associations musulmanes du Mali', Info-Matin, 13 February 2001, pp. 4-5.

43. See, for example, Michael Taussig, Mimesis and Alterity (Routledge, New York, NY, 1993); Homi Bhabha, 'Of mimicry and man', in The Location of Culture (Routledge, New York, NY, 1994), pp. 85-92.

44. On this heightened sense, see Dale F. Eickelman and James Piscatori, Muslim Politics (Princeton University Press, Princeton, NJ, 1996). For Malian press coverage of the OCI meeting, see, for example, 'Organisation de la Conférence islamique. Le monde musulman', Liberté, 3 July 2001, p. 4.

45. See the extensive coverage of the meeting in a special edition of Le Continent, 2 February 2001. 
Perhaps the most explosive issue centred on government plans to reform the laws about the family, usually referred to as the code de la famille (Family Code) in Mali. In 2001, after lengthy discussion and debate over a number of years, the government announced specific proposals for reform in marriage and inheritance law: raising the age for girls to marry, making the husband and wife equal in marriage and men and women equal in inheritance. ${ }^{46}$ All of these changes were to be in accordance with the 1995 Beijing Conference Platform for Action and the subsequent follow-up conference in 2000, which the Malian government, Malian women's rights activists and secular NGOs had advocated and endorsed. For several years, some of Mali's major donors and various NGOs operating in the country have emphasized the importance of such social reforms, which they have sometimes explicitly linked to the other economic and political reforms democratization and liberalization. However, most leaders of Islamic associations charged that the government's proposed changes were in contradiction with the rules of Islamic jurisprudence upon which Malian Muslims ordinarily rely. ${ }^{47}$

In 2002, President Konaré formally presented legal texts to reform the family code and to outlaw the practice of excision. Less than three weeks later, the texts were withdrawn in the face of considerable criticism. If the secular Malian press quickly reported that this was the 'last victory of the Islamists' over the outgoing president, ${ }^{48}$ the government seems to have seriously misjudged the opposition to such reforms. It is unclear to what extent the Malian government took into account neighbouring Senegal's experience of reforming the code de la famille in the 1970s, which also generated widespread opposition from Muslim religious leaders. ${ }^{49}$ In Mali, the imam of the main Friday mosque in Bamako was just one of the most high profile and outspoken of the many Muslim religious leaders who objected to the proposed changes, which they stated clearly and unambiguously violated Islamic precepts. ${ }^{50}$

Before the 2002 presidential elections, outside observers continued to hail Mali as a place where neoliberal reforms and democracy were working.

46. For a discussion of some of the proposed reforms and specific controversies, cf. Benjamin F. Soares, 'The attempt to reform family law in Mali', in Margot Badran (ed.), Gender and Islam in Africa (Brill, Leiden, The Netherlands, forthcoming); Dorothea E. Schulz, 'Political factions, ideological fictions: the controversy over family law reform in democratic Mali', Islamic Law and Society, 10, 1 (2003), pp. 132-64.

47. Birama Fall, 'Islam et politique. La colère des islamistes contre le pouvoir', Le Républicain, 23 April 2001, p. 1; Belco Tamboura, 'Le front religieux, un front de plus pour Konaré', L'Observateur, 14 June 2001, p. 6.

48. C. H. Sylla, 'Code de la famille et excision. La dernière victoire des islamistes sur Alpha', Le Républicain, 10 June 2002, p. 5.

49. See Christian Coulon, Le marabout et le prince: Islam et pouvoir au Sénégal (Pédone, Paris, France, 1981).

50. Boukary Daou, 'Code de la famille et excision. Les musulmans disent non à Alpha', Le Républicain, 5 June 2002, p. 1. 
Despite all the praise, many ordinary Malians talked about the more than ten years of crisis - economic, political, social, even moral - and were openly cynical about democracy and reform. ${ }^{51}$ During those years of crisis, certain Muslim actors, mostly officials, activists, and spokespersons from the new Islamic associations were incredibly busy mobilizing to advance an agenda that did not always sit comfortably with the agenda of President Konaré. After almost ten years of active engagement with the print and audio-visual media, some of them had become rather media savvy. They gave interviews, held press conferences, released public statements and policy prescriptions, perfected their sermon-giving, wrote opinion pieces for newspapers, and got on national television and public and private radio to discuss and debate Islam, Muslim values, morality and sometimes even politics. At the same time, some of them organized meetings, built coalitions, fundraised, networked and lobbied the government. In the end, some of them met with politicians and officials in political parties and endorsed a particular presidential candidate and encouraged people to vote for him, even though he was not elected. Despite their moralizing discourses and critiques of the current state of affairs in Mali, the overwhelming majority of these Malian Muslims seem firmly committed to the idea of democracy. Moreover, they frequently invoke their rights to freedom of expression and association, as well as their rights as citizens to engage in discussion and debate about religion and politics.

Muslim activists' attempts to speak on behalf of other Muslims notwithstanding, it is difficult to say this new Muslim elite is representative of Malian Muslims in all their diversity. With the possible exception of Haïdara's association, Ançar Dine, none of the new Islamic associations in Mali could be considered grassroots organizations. None of the new Muslim religious leaders - again with the exception of Haïdara - even have much popular legitimacy. They nevertheless do seem to speak at least sometimes to the concerns of some ordinary Malians. This is not to assert any sort of primordialist Muslim identity here, or a crude instrumentalism on the part of Malian Muslims or all Muslim activists for that matter. Rather, some Muslim activists seem able to articulate some of the concerns of many ordinary Malian Muslims, who face the contradictions of living as modern Muslim citizens in a modernizing and secularizing state where the 'un-Islamic' seems to be always just around the corner in this age of neoliberal governmentality. Most observers would be reluctant to consider such forms of Muslim activism, which range from efforts at moral reform and discipline to possible challenges to the state's legitimacy, as evidence of the expansion

51. Cf. Michael Bratton, Massa Coulibaly, and Fabiana Machado, 'Popular views of the legitimacy of the state in Mali', Canadian Fournal of African Studies 36, 2 (2002), pp. 197-238; Michael Bratton, Robert Mattes and E. Gyimah-Boadi, Public Opinion, Democracy and Market Reform in Africa (Cambridge University Press, Cambridge, 2005). 
of civil society in Mali. Many Malian secularists and outside observers find such activism alarming and warn of the dangers of political Islam here and further afield. As I have suggested, rather than simply labelling (or denouncing) this as fundamentalism or Islamism, one must understand such developments in Mali in their complex genesis and equally complex transnational connections in this age of neoliberal reforms.

\section{Bibliography of books and articles}

References to other sources, including interviews, archives, newspaper articles, websites and grey publications, are contained in relevant footnotes.

Asad, Talal, 'Religion, nation-state, secularism', in Peter van der Veer and Hartmut Lehmann (eds), Nation and Religion: Perspectives on Europe and Asia (Princeton University Press, Princeton, NJ, 1999), pp. 178-196.

Bah, Ahmad Uthman, Diya' al-ghasaq manzuma nasihat al-shabab (Matba'at al-najah al-jadida, Casablanca, 1992).

Bhabha, Homi, 'Of mimicry and man', in The Location of Culture (Routledge, New York, NY, 1994), pp. 85-92.

Bratton, Michael, Massa Coulibaly, and Fabiana Machado, 'Popular views of the legitimacy of the state in Mali', Canadian Fournal of African Studies 36, 2 (2002), pp. 197-238.

Bratton, Michael, Robert Mattes and E. Gyimah-Boadi, Public Opinion, Democracy and Market Reform in Africa (Cambridge University Press, Cambridge, 2005).

Brenner, Louis, Controlling Knowledge: Religion, power and schooling in a West African Muslim society (Indiana University Press, Bloomington, 2001).

Chatterjee, Partha, The Nation and Its Fragments (Princeton University Press, Princeton, NJ, 1993).

Comaroff, John L. and Jean Comaroff (eds), Civil Society and the Political Imagination in Africa (University of Chicago Press, Chicago, IL, 1999).

Coulon, Christian, Le marabout et le prince: Islam et pouvoir au Sénégal (Pédone, Paris, 1981).

Eickelman, Dale F. and James Piscatori, Muslim Politics (Princeton University Press, Princeton, NJ, 1996).

Ferguson, James and Akhil Gupta, 'Spatializing states: toward an ethnography of neoliberal governmentality', American Ethnologist 29, 4 (2002), pp. 981-1002.

Gosselin, Claudie, 'Handing over the knife: Numu women and the campaign against excision in Mali', in Bettina Shell-Duncan and Ylva Hernlund (eds), Female 'Circumcision' in Africa: Culture, controversy, and change (Lynne Rienner, Boulder, CO, 2000), pp. 193-214.

Hibou, Béatrice and Richard Banégas, 'Civil society and the public space in Africa', CODESRIA Bulletin 1 (2000), pp. 39-47.

Launay, Robert and Benjamin F. Soares, "The formation of an "Islamic sphere" in French colonial West Africa', Economy and Society 28, 4 (1999), pp. 497-519.

Piot, Charles, Remotely Global: Village modernity in West Africa (University of Chicago Press, Chicago, IL, 1999).

Robinson, David, Paths of Accommodation: Muslim societies and French colonial authorities in Senegal and Mauritania, 1880-1920 (Ohio University Press, Athens, OH, 2000). 
Robinson, David and Jean-Louis Triaud (eds), Le temps des marabouts: Itinéraires et stratégies islamiques en Afrique occidentale française v.1880-1960 (Karthala, Paris, 1997).

Roy, Olivier, (trans. C. Volk), The Failure of Political Islam (Harvard University Press, Cambridge, MA, 1994).

Roy, Olivier, Globalized Islam (Columbia University Press, New York, NY, 2004).

Salvatore, Armando, 'Social differentiation, moral authority and public Islam in Egypt: the case of Mustafa Mahmud', Anthropology Today 6, 2 (2000), pp. 12-15.

Schulz, Dorothea E., 'Political factions, ideological fictions: the controversy over Family Law reform in democratic Mali', Islamic Law and Society 10, 1 (2003), pp. 132-64.

Schulz, Dorothea, " "Charisma and Brotherhood" revisited', fournal of Religion in Africa 33 (2003), pp. 146-71.

Shell-Duncan, Bettina and Ylva Hernlund (eds), Female 'Circumcision' in Africa: Culture, controversy, and change (Lynne Rienner, Boulder, CO, 2000).

Soares, Benjamin F., Islam and the Prayer Economy: History and authority in a Malian town (Edinburgh University Press, Edinburgh, and the University of Michigan Press, Ann Arbor, MI, 2005).

Soares, Benjamin, 'Mali: Im Visier der Islamismus-Fahnder', INAMO 41 (2005), pp. 16-18.

Soares, Benjamin F., 'Islam and public piety in Mali', in Armando Salvatore and Dale F. Eickelman (eds), Public Islam and the Common Good (Brill, Leiden, 2004), pp. 205-26.

Soares, Benjamin F., 'Notes on the anthropological study of Islam and Muslim societies in Africa', Culture and Religion 1, 2 (2000), pp. 277-85.

Soares, Benjamin F., 'Muslim proselytization as purification: religious pluralism and conflict in contemporary Mali', in Abdallah A. An-Na'im (ed.), Proselytization and Communal Self-Determination in Africa (Orbis, Maryknoll, NY, 1999), pp. 228-45.

Soares, Benjamin F., 'The attempt to reform Family Law in Mali', in Margot Badran (ed.), Gender and Islam in Africa, (Brill, Leiden, forthcoming).

Starrett, Gregory, 'The political economy of religious commodities in Cairo', American Anthropologist 97, 1 (1995), pp. 51-68.

Tall, Amadou, Dimensions de l'islam (Dar El Fikr, Beirut, 1995-1996).

Taussig, Michael, Mimesis and Alterity (Routledge, New York, NY, 1993).

Tsing, Anna L. In the Realm of the Diamond Queen: Marginality in an out-of-the-way place (Princeton University Press, Princeton, NJ, 1993).

United States Agency for International Development, USAID MALI: Country Strategic Plan 2003-2012 (USAID, Bamako, 2002). 